\title{
Gender Differences in Using Apology Strategies in Jordanian Spoken Arabic
}

\author{
Rawan E. Al-Sallal ${ }^{1} \&$ Madani O. Ahmed ${ }^{1}$ \\ ${ }^{1}$ Department of English Language, University of Bahrain, Sakhir, Bahrain \\ Correspondence: Rawan Al-Sallal, Department of English Language, University of Bahrain, Sakhir, Bahrain. \\ E-mail: rawansallal@gmail.com
}

\author{
Received: July 12, $2020 \quad$ Accepted: August 11, $2020 \quad$ Online Published: August 17, 2020 \\ doi:10.5539/ijel.v10n6p54 URL: https://doi.org/10.5539/ijel.v10n6p54
}

\begin{abstract}
This study investigated apology strategies used in Jordanian spoken Arabic. The main purpose was to find whether gender plays a role in selecting apology strategies related to different situations. A modified version of Harb's discourse questionnaire was employed for collecting the data. The participants included 20 males and 20 females. The data were codified and classified using Cross-Cultural Speech Act Realization Patterns (CCSARP), by Blum-Kulka and Olshtain (1984). Both qualitative and quantitative approach was used in analysing the collected data. The findings of the study demonstrate that there are more similarities than differences between females and males in the use of apology strategies. In addition, it was found that both groups tend to use multiple apology strategies in the same utterance; however, their strategies vary in frequency. The results demonstrated that there is no substantial quantitative difference in the use of apology strategies between Jordanian males and females. Further research employing a multi-factor framework (age, gender, education) of addressees is needed.
\end{abstract}

Keywords: speech acts, gender, apology strategies, politeness, face threatening

\section{Introduction}

Linguists such as Olshtain and Cohen (1983), Trosborg (1987), Meier (1998) and others believe that people from different social backgrounds have different ways of expressing apology. Searle (1969) considered strategies of apology as a universal feature "based on universal felicity conditions" (Salgado, 2011, p. 29). Salgado argued that apology strategies are "general mechanisms" that are "essentially identical across different cultures and languages and any differences that may exist are not that important" (p. 28). Searle (1969) and Leech (1983) added that apologies vary only in verbalisation and conceptualisation in every language.

Comparing apology speech according to gender is very important in the field of sociolinguistics and cross-cultural pragmatics. Since the 1970s, sociolinguists have been intrigued by the role of gender differences in linguistics variation in different social contexts. Although researchers have tested the effect of social variation such as class, age, and gender, fewer studies have been conducted on the impact of gender apology utterances. Most have focused on the phenomenon from its overall pragmatic nature as a social factor rather than being related to gender differences. Consequently, this study attempted to answer the following questions:

1) What are the apology strategies used by native speakers of Jordanian Arabic?

2) What are the similarities and differences in the use of apology strategies between female and male respondents?

\subsection{Definition of Speech Act, Politeness, and Apology}

Austin (1962) defined a speech act as a performed utterance for a specific function during communication, such as apology. Cohen and Olshtain (1981), Fromkin and Rodman (1988), and Hatch (1992) added that apology is not related to the speech act and language knowledge alone, but is determined by the use of language in a given culture. Celce-Murcia and Olshtain (2000) emphasised the importance of being aware of any difference that may occur in a discourse between L1 and L2, ensuring the acquisition of pragmatic competence of L2. Searle (1969) in his book "How to do things with words" broadened the view of the speech act and included the characteristics of uttering expressions according to specific regulative and constitutive rules. Regulative rules regulate behaviour forms, while constitutive rules regulate and create new behaviour forms. He introduced a theoretical framework in which he added meanings, actions, and utterances to the speech act as a whole. For example, the 
speech act has four main branches: utterances, illocutionary utterance, propositional utterance, and perlocutionary utterance. Searle also added five functions to the speech act: representative, expressive, directive, co-missives, and declaration.

Most scholars prefer to use the word "politeness" as it refers to behaviour that is "developed in societies to reduce friction in personal interaction" (Lakoff, 1975, p. 45). Politeness is defined as a verbal behaviour that creates harmonious interaction (Fraser \& Nolan, 1981; Leech, 1983). Eelen (2001) clarified two views of politeness: the common sense of politeness which he called Politeness 1, while Politeness 2 is the scientific conceptualisation. "Politeness one concept should not just be different from politeness two concepts, or given different names, but rather the relationship between both notions should be carefully monitored throughout the entire analytical process not only at the input stage" (p. 31). Eelen as cited in connected politeness with culture, in that "communicative success depends on the right amount and kind of politeness applied at the right time to the right speech act, as it is determined by social norms "that stipulate what is appropriate for a specific interactional situation" (2001, p. 128).

Holmes (1989) defined apology as a "speech act addressed to V's face-needs and intended to remedy an offence for which $\mathrm{A}$ takes responsibility, and thus to restore equilibrium between $\mathrm{A}$ and $\mathrm{V}$ where $\mathrm{A}$ is the apologist, and $\mathrm{V}$ is the victim or person offended" (p. 196). He considered apology as "primarily social acts, carrying the effective meaning" (p. 155). Holmes's contribution is parallel to Brown and Levinston's $(1978,1987)$ theoretical framework of politeness theory in which they determined apology as a politeness strategy. According to Brown and Levinston, illocutionary acts of apology can be considered as either negative or positive politeness strategies. Thus, these strategies may constitute a face-threatening situation if it is considered a negative politeness strategy which causes damage to the apologiser's positive face. However, Holmes (1990) emphasised that it is still serving positive and negative faces if it is considered negative by the speaker's face, while the hearer considers it as a positive face act. Only if it is used for requesting forgiveness is it considered a negative face-threatening act for the hearer.

Apology for Marquez Reiter (2000) is a "compensatory action for an offence committed by S (the speaker) which has affected H (the hearer)" (p. 44). Whereas Olshtain (1989) defined it as "a speech act which is intended to provide support for the $\mathrm{H}$ (hearer) who was actually or potentially affected by a violation $\mathrm{X}$, the $\mathrm{S}$ (speaker) is willing to humiliate himself or herself to some extent and to admit to fault and responsibility for X" (p. 156). Gooder and Jacobs (2000) as cited in Ghanbari et al. (2015, p. 205), added that "proper apology acknowledges the fact of wrongdoing, accepts ultimate responsibility, expresses sincere sorrow and regret, and promises not to repeat the offence". Therefore, "some of the features of the proper apology are the admission of trespass, the implied acknowledgement of responsibility, an expression of regret, and a promise of a future in which injury will not recur". Garcia (1989) elaborated that apology is a matter of:

Explanation offered to a person affected by one's action that no offense was intended, coupled with the expression of regret for any that may have been given; or, a frank acknowledgment of the offense with expression of regret for it, by way of reparation (p. 44).

All of these definitions have three major similarities that can be summarised as follows: An apology is a social act between two parties, victim (speaker) and apologiser, to sustain a relationship.

\subsection{Studies on Apology in English}

Many studies have focused on the use of apology strategies in second language learning. One of the most considerable developments in the field of speech act studies was the "speech act realisation project" (CCSARP) developed by Blum-Kulka and Olshtain in 1984. Their goal was to investigate the impact of cultural background on speech acts of requests. They examined native speakers of languages including French, German, Australian English, American English, Spanish and Russian. Data were collected through a discourse completion test (DCT). The received data are attributed to three major variables: situational (intra-cultural), cross-cultural, and individual variables. They found that the act of apology was performed under a specific category or a combination of the following types: illocutionary force indicating device (IFID), state responsibility (RESP), provide explanation (EXPL), offer to repair (REPR), and promise of forbearance (FORB). The first category includes performative verbs which state apologies like 'forgive me!'. Accepting responsibility includes a range of acceptance from being placated or self-humbling toward the complainer to fault denial. The last three categories are associated with the violation happening in an apology situation. It is worth noting that the category which includes 'promise of forbearance' is offered by expressing responsibility, although it is not always an explicit apology.

Blum-Kulka and Olshtain's (1984) CCSARP gave rise to studies on the speech act of apology. One of the 
influential studies was conducted by Trosberg in 1987, who tested native speakers of British English and Danish learners of English. The study was divided into two major parts. Trosberg classified apology strategies and analysed these strategies according to the participants' behaviour, emphasising the fundamental issue of face-saving maxims in face-to-face interactions. He concluded with two attitudes to face saving: a defensive attitude to protect own face and a protective attitude to protect the other's face. Bergman and Kasper (1993) conducted experimental research on Thai native speakers and English native speakers, focusing on both the perception and the performance of each party in different contexts. Most of the participants' choices are toward stating their responsibilities and offering explicit apologies. Sugimoto (1997) compared American and Japanese apology strategies and reported that "statement of remorse, description of damage, and reparation" were the most-used strategies. Finally, Vollmer and Olshtain (1989) examined the realisation patterns of apology by Germans to determine the effects of social status. The results revealed that most participants use IFIDs and RESP which were related to the situational parameters.

\subsection{Studies on Apology in Arabic}

Unlike other languages, little research has been carried out on the realisation of apology of native speakers of Arabic. One study was by Qari (2019), who investigated cultural differences in the use of apology strategies between Saudi and British people in terms of gender. She found differences between Saudi and British participants in the selection of apology strategies specially when the addressee was a male. Jassim and Nimehchisalem (2016) studied EFL Arab students' apology strategies. They found out that the apology with Illocutionary Force Indicating Device (IFID) was used more frequently than other strategies. They also concluded that Arab students preferred to use more than one apology strategy in formal contexts. Harb (2016), who tested whether gender plays a role in the apology strategies employed by native Arabic speakers from Saudi Arabia, Jordan and Egypt and found no statistically significant differences. Abu Humei (2013) collected data by the use of an online discourse completion task which targeted Iraqi learners of English and American native speakers of English. He compared two variables: gender and status. The results showed that Iraqi males apologised more to people of higher status, while Americans apologised more frequently to people of a lower status.

Alzumor (2011) conducted research to explore the inter-language pragmatics in expressing apology in English by Arab learners of English, and then compared these results with those of British and American English speakers. He concluded that the culture of Arabs "admitting one's deficiency to set the things right is not as embarrassing as in the Anglo-Saxon cultures" (2011, p. 28). Therefore, he determined the cause of his findings as the impact of the close relationship between Arabs and their lack of fear of having no immunity in social relations. Bataineh and Bataineh (2006) investigated apology strategies used by Jordanian female/male EFL learners at college. Their study indicated that there are differences in the selection and order of the primary strategies used by each group. Sinan (2004) tested the use of apology in English by Arabs in India. He found some differences in the use of apology resulting from variations in religious belief, values, social status, etc. Arab learners attempted to use multiple or repetition of words 'I am so so sorry' to show the sincerity of apology. Soliman (2003) compared apology strategies of American and Egyptian participants. The result shows similarities in intensifiers, interjections, expressing embarrassment, while some differences were reported in Egyptian results and their use of praising in God's name.

Hussein and Hammouri (1998) compared American native speakers and Jordanian learners of English. The findings revealed that Americans used fewer strategies than Jordanians. They were similar in their use of some apology strategies like REPR and RESP but, in some situations, Jordanians tried to prevent the use of apology strategies by praising in the name of God in an attempt to convince the other party. Rizk (1997) studied apology strategies used by Saudi, Palestinian, Moroccan, Syrian, Lebanese, Jordanian, Yemeni, Tunisian, Libyan, and Egyptian participants. He found that Arabs did not apologise in situations where the addressees were children; instead, they preferred to make children forgive them in an indirect speech like (do not feel sad!) and offering food, which can be considered as rude behaviour by native speakers. This shows the significant role of cultural patterns, in which food for some cultures like the Arab is an indication of forgiveness and wiping out hurt and blame. Al-Hami (1993) studied apology strategies used by Arab learners and native speakers of the English language, including the use of responsibility statements, repair, concern, forbearance, and expressing explicit apology. He further shed light on the use of apology intensification by Arabs 'I am very very sorry'. Although similar strategies were used which may refer to the universality of the speech act, significant differences were found between the performance of Arabs and native speakers of English. Al-Hami explained these differences as evidence of negative transfer of cultural variation and lack of linguistic competence.

Holmes (1990) pointed out that "most females enjoy talk and regard talking as an important means of keeping in 
touch, especially with friends and intimates. They use language to establish, nurture and develop personal relationships". However, he added that "males tend to see language more as a tool for obtaining and conveying information" (p. 2). Holmes found that females apologised more than males to a hearer of equal power, while males apologised to females regardless of their status. Cameron (1997) and Bergvall (1996) argued that comparing males' and females' speech act will show cultural differences and other factors such as class and stereotypes. The majority of the studies referred to above agree on the universality of apology as a speech act; that is, the need to apologise in a given circumstance using a particular linguistic expression to alleviate any negative effect. Slight differences of opinion do exist, however, as some researchers have found more contrasts than similarities, while others have discovered the opposite. Testing this speech act therefore remains important. This paper concentrates on investigating the effect(s) of gender on the selection of apology strategies in Jordanian Arabic.

\section{Method and Data Analysis}

Two groups of native speakers of Jordanian Arabic, 20 females and 20 males, were randomly selected. All participants had at least a bachelor degree, and they were between 20 and 40 years old. Data were collected until saturation point was reached. The researchers used a Discourse Completion Test (DCT) adopted from previous research, Mustafa Ali Harb (2016). The adopted test consisted of ten statements that presented a variety of social situations, and the participants were asked to respond to these situations in Jordanian Arabic. The DCT was distributed online and completed in informal (natural) situations/environments where participants felt free and were not hesitant to express their attitude toward each social situation. The researchers indicated the purpose of the study to all participants, assuring them of the confidentiality of the answers, and confirming their willingness to complete the questionnaire.

The CCSARP framework of Blum Kulka and Olstain (1989) was used in analysing the collected data. It includes five strategies: implicit and explicit apology expressions, explanation of the situation, offer of repair, responsibility acknowledgement, and the promise of forbearance. This framework has been widely used by researchers such as Wilson (2018), Alzeebaree and Yavuz (2017), and Murphy (2015). The data were analysed quantitatively and qualitatively to identify possible differences in the responses between females and males. The quantitative method was statistical analysis to present the most used strategies, while qualitatively the researchers categorised the responses to the DCT questionnaire.

\section{Results}

This study was conducted to investigate the use of apology strategies by native speakers of Jordanian Arabic and how apologies are realised. It also set out to discover the impact of gender, if any, on the respondents' choices of apology strategies. First, it is necessary to discuss what participants are apologising for, and to whom. An apology is an act which expresses one's emotions to help in rebuilding social harmony after a situation of conflict, "to evince good manners, to assuage the addressee's wrath, or simply to get off the hook and be on one's way" (Norrick, 1978, p. 280). The realisation of the communicative function and the situation in which an apology occurs are defined in order to understand the Jordanian community and their way of expressing apology, which undoubtedly differs than the western situation. It is worth mentioning that this study focused on the form and the most frequently used strategies between Jordanians, while the function will be examined in further research.

\subsection{Holistic View}

Table 1 presents the overall percentage and frequency of apology strategies.

Table 1. Apology strategies frequency, percentage, mean, and standard deviation

\begin{tabular}{|c|c|c|c|c|c|c|}
\hline \multirow[t]{2}{*}{ Apology Strategy } & \multicolumn{2}{|c|}{ Female } & \multicolumn{2}{|l|}{ Male } & \multirow[t]{2}{*}{ Mean } & \multirow[t]{2}{*}{ Standard Deviation } \\
\hline & $\bar{F}$ & $\%$ & $F$ & $\%$ & & \\
\hline IFID & 60 & $32 \%$ & 58 & $29 \%$ & 59 & 1.41 \\
\hline EXPL & 74 & $39 \%$ & 79 & $40 \%$ & 76.5 & 3.54 \\
\hline REPR & 31 & $15.50 \%$ & 36 & $17.50 \%$ & 33.5 & 3.54 \\
\hline RESP & 24 & $13 \%$ & 26 & $13 \%$ & 25 & 1.41 \\
\hline FORB & 1 & $0.50 \%$ & 1 & $0.50 \%$ & 1 & 0.00 \\
\hline Mean & 38 & $20 \%$ & 40 & $20 \%$ & & \\
\hline Total & 190 & $100 \%$ & 200 & $100 \%$ & & \\
\hline SD & 29.1 & & 29.90 & & & \\
\hline
\end{tabular}


In general, Jordanians preferred to use multiple strategies in performing apology which is consistent with the result of Harb (2016) and Jassim and Nimehchisalem (2016). Although all strategies were used, participants preferred some over others. EXPLs represented the highest exchanges $(\mathrm{n}=153 ; 39 \%)$, then IFIDs $(\mathrm{n}=118$; $30 \%)$ which were combined with other strategies. REPR was the third most-used strategy, occurred 67 times $(17 \%)$, while RESP was used 50 times (13\%), and FORB only twice $(0.5 \%)$. Overall, little or no difference was found between females' and males' use of apology strategies as Table 2 shows. The data proved to be normally distributed using Shapiro-Wilk on SPSS (males: Sig. $=985$, females: Sig. $=873$ ) and as a result, Independent t-test was used to test the significance of the difference between females and males in the use of apology strategies (Table 2).

Table 2. Independent t-test of the difference between female and male participants

\begin{tabular}{|c|c|c|c|c|c|c|c|c|c|c|}
\hline \multicolumn{4}{|c|}{ Levene's Test for Equality of Variances } & \multicolumn{7}{|c|}{ t-test for Equality of Means } \\
\hline & & \multirow[t]{2}{*}{$\mathrm{F}$} & \multirow[t]{2}{*}{ Sig. } & \multirow[t]{2}{*}{$\mathrm{t}$} & \multirow[t]{2}{*}{$\mathrm{df}$} & \multirow[t]{2}{*}{$\begin{array}{l}\text { Sig. } \\
\text { (2-tailed) }\end{array}$} & \multirow[t]{2}{*}{$\begin{array}{l}\text { Mean } \\
\text { Difference }\end{array}$} & \multirow[t]{2}{*}{$\begin{array}{l}\text { Std. Error } \\
\text { Difference }\end{array}$} & \multicolumn{2}{|c|}{$\begin{array}{l}95 \% \text { Confidence Interval } \\
\text { of the Difference }\end{array}$} \\
\hline & & & & & & & & & Lower & Upper \\
\hline \multirow[t]{2}{*}{$\begin{array}{l}\text { Mean } \\
\text { Occurrence }\end{array}$} & $\begin{array}{l}\text { Equal variances } \\
\text { assumed }\end{array}$ & .002 & .966 & .107 & 8 & .917 & 2.00000 & 18.67083 & -41.05502 & 45.05502 \\
\hline & $\begin{array}{l}\text { Equal variances } \\
\text { not assumed }\end{array}$ & & & .107 & 7.994 & .917 & 2.00000 & 18.67083 & -41.06024 & 45.06024 \\
\hline
\end{tabular}

As can be seen from Tables 1 and 2, there is no significant difference between male participants $(M=40, S D=$ $29.90)$ and female participants $(\mathrm{M}=38, \mathrm{SD}=29.129) ; t(8)=.107, p=.917$ at 0.05 level. This indicates clearly that there was no significant effect of gender on the use of the types of apology strategies.

\subsection{Atomistic View}

The collected data were categorised, according to the adopted framework, into five apology strategies. The following sections present and discuss each strategy and its sub-strategies and the result of each type of strategy in detail.

\subsubsection{The Illocutionary Force Indicating Device}

One of the most common strategies used by males and females is the illocutionary force indicating device (henceforth IFIDs) which is correspondent with Harb (2016) and Jassim and Nimehchisalem (2016) findings. IFIDs can be divided into: (1) regret expression (e.g., asef (I am sorry)), (2) offering apology (e.g., ana aatather (I apologise)), and (3) asking for forgiveness (e.g., samhyni (forgive me!)). The overall frequency of IFIDs is 118 (Table 3), representing 30\% of the apology strategies $(\mathrm{n}=390)$ used by Jordanian speakers. Both gender groups employed IFIDs in nearly all situations. The female participants used $32 \%(\mathrm{n}=60)$, and males used $29 \%$ $(\mathrm{n}=58)$.

Table 3. IFIDs frequency and percentage

\begin{tabular}{lllll}
\hline Question number & Female & \multicolumn{3}{c}{ Male } \\
\cline { 2 - 5 } & Frequency & Percentage & Frequency & Percentage \\
\hline 1 & 10 & $40 \%$ & 6 & $25 \%$ \\
2 & 5 & $28 \%$ & 6 & $35 \%$ \\
3 & 2 & $12 \%$ & 9 & $36 \%$ \\
4 & 5 & $38 \%$ & 9 & $45 \%$ \\
5 & 6 & $38 \%$ & 10 & $34 \%$ \\
6 & 7 & $35 \%$ & 2 & $13 \%$ \\
7 & 11 & $42 \%$ & 11 & $48 \%$ \\
8 & 5 & $22 \%$ & 2 & $10 \%$ \\
9 & 2 & $15 \%$ & 1 & $9 \%$ \\
10 & 7 & $32 \%$ & 2 & $13 \%$ \\
Overall & 60 & $32 \%$ & 58 & $29 \%$ \\
\hline
\end{tabular}

According to the overall statistics, IFIDs represented the second highest apology strategy after EXPL. In Table 3, situation number 7 represents the highest number of instances $(n=11 ; 42 \%)$ of the use of IFIDs for females, while situations number 3 and 9 are the lowest number of instances $(n=2 ; 12 \%)$. This can be explained by 
referring to the addressee's status. In situation number 7, the addressee is an old woman who has fallen down. In general, old people receive a high degree of respect and obeisance in Jordanian culture regardless of gender status, social distance and other variation. This may explain the high usage of IFIDs, especially in this situation. As for situations 3 and 9, both status and damage are minimum, explaining the low level of instances. For males, situation number 7 also received the highest number of instances of IFID $(n=11,48 \%)$, and situation number 9 the lowest $(n=1,9 \%)$. It is worth mentioning that IFIDs were used with multiple apology strategies, indicating sensitivity by trying to show sympathy and save the face of the addressees.

\subsubsection{Explanation}

Explanation (henceforth EXPL) is another apology strategy used to reduce the impact of face violation and any conflict. Explanations can be divided into (1) implicit (e.g., knt mrydah (I was sick)) and (2) explicit explanation strategies (e.g., sar endy zarf tariq (I had an emergency)). In correspondence with Harb's (2016) findings, the participants' use of explanations had the highest number of instances by both gender groups $(n=153)$. As can be seen in Table 4, the EXPLs were employed in all situations.

Table 4. EXPLs frequency and percentage

\begin{tabular}{lllll}
\hline Question number & Female & \multicolumn{3}{l}{ Male } \\
\cline { 2 - 5 } & Frequency & Percentage & Frequency & Percentage \\
\hline 1 & 5 & $20 \%$ & 9 & $38 \%$ \\
2 & 9 & $50 \%$ & 8 & $47 \%$ \\
3 & 12 & $71 \%$ & 10 & $40 \%$ \\
4 & 6 & $46 \%$ & 8 & $40 \%$ \\
5 & 8 & $50 \%$ & 13 & $45 \%$ \\
6 & 9 & $45 \%$ & 11 & $73 \%$ \\
7 & 7 & $27 \%$ & 6 & $26 \%$ \\
8 & 7 & $30 \%$ & 8 & $38 \%$ \\
9 & 4 & $31 \%$ & 4 & $36 \%$ \\
10 & 7 & $32 \%$ & 2 & $13 \%$ \\
Overall & 74 & $39 \%$ & 79 & $40 \%$ \\
\hline
\end{tabular}

For females, the highest frequency is in situation $3(n=12 ; 71 \%)$, and the lowest in situation $9(n=4 ; 31 \%)$. The high frequency in situation 3 is due to its seriousness, a conversation about missing an exam; while in situation 9 the harm is not serious and there is an opportunity for negotiation. The frequency of EXPLs among male participants was different. As Table 4 above demonstrates, the highest number of instances was in situation 5 (n $=13 ; 45 \%)$, and the lowest in situation $10(\mathrm{n}=2 ; 13 \%)$. Confirming the earlier discussion, in the overall results males tended to apologise more to non-relatives. Situation number 10 involved borrowing a CD from a friend. Males provided explanations and offered multiple apologies with friends, due to the strength and the status of the relationship. Alternatively, because of mother's status in Jordanian culture, some speakers provided explanations related to mothers' orders, appointments and others, which are considered as convenient excuses for the addressee.

\subsubsection{Offer of Repair}

In Table 5, offer to repair (henceforth REPRs) is the third most-used strategy observed in apology responses of Jordanian females and males. Participants offered to compensate by future action for the damage they had done. In situation 1, one example of REPR is Bukra bashtarilak ktab jdid (Tomorrow I will buy for you a new book), in which the speaker offered a new book instead of the damaged one as a way of repairing. REPRs were utilised 67 times, which constitutes $17 \%$ of the strategies used by both groups. Thirty-one occurrences (16\%) were by females, and $36(18 \%)$ by males. This result agrees with Jassim and Nimehchisalem's (2016) finding that repairing the offense had moderate frequency, but it disagrees with Bataineh and Bataineh's (2006) results in which this strategy had a higher rank. 
Table 5. REPRs frequency and percentage

\begin{tabular}{lllll}
\hline Question number & Female & \multicolumn{3}{l}{ Male } \\
\cline { 2 - 5 } & Frequency & Percentage & Frequency & Percentage \\
\hline 1 & 5 & $20 \%$ & 2 & $8 \%$ \\
2 & 0 & $0 \%$ & 1 & $6 \%$ \\
3 & 3 & $18 \%$ & 5 & $20 \%$ \\
4 & 0 & $0 \%$ & 0 & $0 \%$ \\
5 & 2 & $13 \%$ & 6 & $21 \%$ \\
6 & 2 & $10 \%$ & 2 & $13 \%$ \\
7 & 3 & $12 \%$ & 1 & $4 \%$ \\
8 & 8 & $35 \%$ & 10 & $48 \%$ \\
9 & 3 & $23 \%$ & 2 & $18 \%$ \\
10 & 5 & $23 \%$ & 7 & $47 \%$ \\
Overall & 31 & $16 \%$ & 36 & $18 \%$ \\
\hline
\end{tabular}

The highest frequency of REPRs for females $(n=8 ; 35 \%)$ and males $(n=10 ; 48 \%)$ was in situation 8 (breaking a promise to a child). Situations 2 (meeting with a friend at the library) and 4 (meeting with his/her English teacher) indicated the lowest frequency of this strategy by males $(\mathrm{n}=1,6 \%)$, and no occurrence was found in females' responses. In these two situations, REPR cannot be considered a convenient way of apologising especially that in these two situations repairs would not have reduced the violation impact. In other words, REPR is time-sensitive, meaning that not every situation repair can be considered as a solution, so in certain situations no REPR was offered at all.

\subsubsection{Taking Responsibility}

Admitting and declaring responsibility for the damage or the offence was shown as lack of intention (e.g., $m a$ intabaht), an embarrassment (e.g., muhraj minak) or accepting blame (e.g., hagak alai). Unlike some previous studies, declaring responsibility (henceforth RESPs) came fourth, while in Jassim and Nimehchisalem's (2016) study it was in the third position and the second in Bataineh and Bataineh's (2006) results. As can be seen from Table 6, the RESPs had a frequency of 50 instances (13\%). Of the 50 occurrences, 21 (13\%) instances were employed by Jordanian females and 22 instances (13\%) by males.

Table 6. RESPs frequency and percentage

\begin{tabular}{lllll}
\hline Question number & Female & \multicolumn{3}{l}{ Male } \\
\cline { 2 - 5 } & Frequency & Percentage & Frequency & Percentage \\
\hline 1 & 5 & $20 \%$ & 7 & $29 \%$ \\
2 & 3 & $17 \%$ & 2 & $12 \%$ \\
3 & 0 & $0 \%$ & 1 & $4 \%$ \\
4 & 2 & $15 \%$ & 3 & $15 \%$ \\
5 & 0 & $0 \%$ & 0 & $0 \%$ \\
6 & 2 & $10 \%$ & 0 & $0 \%$ \\
7 & 5 & $19 \%$ & 5 & $22 \%$ \\
8 & 3 & $13 \%$ & 1 & $5 \%$ \\
9 & 1 & $8 \%$ & 3 & $27 \%$ \\
10 & 3 & $14 \%$ & 4 & $27 \%$ \\
Overall & 24 & $13 \%$ & 26 & $13 \%$ \\
\hline
\end{tabular}

The highest frequency of RESP in females' responses was found in situations 1 and $7(n=5 ; 20 \%)$. This may be attributed to the high degree of guilt especially in situation 7 where participants admitted responsibility for harm that had happened to an old woman. However, RESP was not used in situations 3 and 5. This may be accounted for in terms of the low degree of face threatening which does not permit declaration of responsibility. With male participants, situation 1 had the highest number of RESP instances $(n=7 ; 29 \%)$, while this strategy was not observed in situations 5 and 6 . In situation 1, the violation had already taken place so the use of RESP can be beneficial. Although admitting responsibility in situation 5 and 6 would not have reduced its impact, it can be replaced with other strategies (e.g., REPR).

\subsubsection{Promise of Forbearance}

This strategy, in general, is a promise of not repeating the offence again which indicates a guilty conscience and 
remorse toward the addressee. An example of this strategy was Wallah ma rah a'eedha which means that the offence will not be repeated. Promise of Forbearance (henceforth FORB) is the least frequently used of all the apology strategies, constituting only $1 \%$ of all the apology strategies used and addressed once by each group. Table 7 below displays the use of FORBB across all 10 situations. Both female and male participants had only 1 exchange.

Table 7. FORBs frequency and percentage

\begin{tabular}{lllll}
\hline Question number & Female & \multicolumn{3}{l}{ Male } \\
\cline { 2 - 5 } & Frequency & Percentage & Frequency & Percentage \\
\hline 1 & 0 & $0 \%$ & 0 & $0 \%$ \\
2 & 1 & $6 \%$ & 0 & $0 \%$ \\
3 & 0 & $0 \%$ & 0 & $0 \%$ \\
4 & 0 & $0 \%$ & 0 & $0 \%$ \\
5 & 0 & $0 \%$ & 0 & $0 \%$ \\
6 & 0 & $0 \%$ & 0 & $0 \%$ \\
7 & 0 & $0 \%$ & 0 & $0 \%$ \\
8 & 0 & $0 \%$ & 0 & $0 \%$ \\
9 & 0 & $0 \%$ & 1 & $9 \%$ \\
10 & 0 & $0 \%$ & 0 & $0 \%$ \\
Overall & 1 & $1 \%$ & 1 & $1 \%$ \\
\hline
\end{tabular}

Of the 10 situations, one participant in each group employed FORB only once in situation 2 by a female participant and in situation 9 by a male. This result is in agreement with Harb's study in which he concluded, based on statistics, that Arabs tend to avoid taking responsibility or giving promises of forbearance as the may cause more face threatening than other strategies (p. 253).

\section{Discussion}

This study examined the strategies used in Jordanian apologies. It investigated whether gender has an effect on the selection of apology strategies. It was observed that females' dominant and most frequent responses were ana mtasfh (feminine: I am sorry), ana asfh (masculine: I am sorry), and samhyni (both feminine and masculine in addressing a male; forgive me!). Females used polite strategies like expressions of gratefulness, congratulation, and consolation. However, males preferred to use convincing strategies like praising the name of God, declaring that would take a photo as an evidence. With children, females used ana asfh (I am sorry), while males tried to avoid apology and replaced it with an explanation, blaming, or making further offers. Females used intimate nicknames as expressions of endearment in many situations, as when an old woman fell down, like hajeh, khalto (my aunt), habibty (my love), and omri (my life), and offered help with an explanation. Males used identification words like sadiqi (my friend), malem, habiib, and ya kbiir which were not intended to indicate endearment, but rather to give a status and position of musculinity between males instead of an overt display of affection.

Unlike males who apologised more to foreigners, it was found that females used direct apologies more with friends and relatives, while replacing their apologies with explanations, regressions or offering indemnity or help to foreigners. This can be explained by cultural expectations, as females are considered to be related to family and friends, while males are expected to engage more in formal situations with non-relatives in their daily jobs.

In situation number seven, some respondents overstated apology statements, like asef asef asef. Both males and females used excessive apology expressions including ana mtasfh (I apologise), ana asfh (I am sorry), and samhyni (forgive me!). Interestingly, the researchers ecognised a certain identical strategy used by both groups that can be called 'predict or offer the response' in which they directed the addressee to choose his/her response as a technique to prevent any reaction, regret or propitiation, like akid rah titfahamny, mashiiha hal marra, walak hiia aldinya taayreh by females, while some males responded with walla ink ibn halal...lissa bsiirtak, Basha lissa bidak il CD, Khalas zakirni elyum, batmana tiidli el imtihan and sadiqnii. Another way of preventing any blame is by the use of humour and replacement, although it was rarely used by females and more frequently by males, as follows:

Female:

mawa'idi salata 
mu beina habibbti ana heik daya'a

Male:

akhuy lazim ydhr mawahbu

ma fe majal altizm bl waqt... min yum yummy mitawid a hal harakat

wabaadin...kul yum azmeh...shaware mitl el ama

ylan hazi...kul mara fi hadith

ma baqdar aaji la ahsan ma ahli dkhalooni anam bara el dar

il hajeh ajqatni

Haretni shira irhamni...hi waqafat al yum,isma tara ana masghul u mish fadiilak

bisabb il zahaymer nesiit arajuh

Females also tried to prevent direct apology in certain situations by placing blame or changing the subject, like winek liish taakharti, mmkin tistani alai, mushkiltik t'akhrti mu mushkilti.

\section{Conclusion and Suggestions for Further Research}

The study set out to achieve two goals: (a) identifying apology strategies used by Jordanians and their frequency of occurrence; and (b) investigate the effect of gender on the choice of apology strategies. The findings showed that Jordanians tend to use multiple apology strategies (IFIDs, EXPLs, REPRS, RESPs, and FORBs). In addition, it was found out that these strategies vary widely in their frequency of occurrence. As for the second objective of this study, there were no significant differences found based on gender in terms of apology strategies used in all the 10 scenarios included in the analysis. This finding is consistent with Abu Humeid's (2013) results which indicate slight differences between Iraqi females and males performance of apology. Unlike some previous research, for example Qari (2019) and Bataineh and Bataineh (2006), this study recorded more similarities than differences between the genders. Jordanian females and males employed IFIDs, EXPLs, and REPRs most frequently. Also, both groups preferred to combine strategies, especially EXPLs and IFIDs. They avoided the use of FORB in an attempt to prevent any face threatening. Further research combining DCT and natural interviews, as well as focusing on the age and gender of the addressees, is recommended to provide a clearer reflection of the effect of gender on the use of apology strategies. This suggested future line of research requires a bigger sample of participants.

\section{Acknowledgments}

The author(s) declared no potential conflicts of interest with respect to the research, authorship, and/or publication of this article. The authors received no financial support or specific grant for the research, authorship and/or publication of this article from any funding agency in the public, commercial, or not-for-profit sectors.

\section{References}

Abu Humeid, A. (2013). The Effect of Gender and Status on the Apology Strategies used by American Native Speakers of English and Iraqi EFL University Students. Research in Humanities and Social Sciences, 3(2), 145-173. https://doi.org/10.5539/ijel.v3n2p98

Al-Hami, F. (1993). Forms of apology used by Jordanian speakers of EFL: A cross-cultural study. Unpublished Master's Thesis.

Al-Zumor, A. (2011). Apologies in Arabic and English: An inter-language and Cross-Cultural Study. Journal of King Saud University, 23, 19-28. https://doi.org/10.1016/j.jksult.2010.02.001

Alzeebaree, Y., \& Yavuz, M. A. (2017). Realization of the Speech Acts of Request and Apology by Middle Eastern EFL Learners. Eurasia Journal of Mathematics, Science and Technology Education, 13(11), 7313-7327. https://doi.org/10.12973/ejmste/79603

Austin, J. (1962). How to do Things with Words. Oxford: Oxford University Press.

Bataineh, R., \& Bataineh, R. (2006). Apology Strategies of Jordanian EFL University Students. Journal of Pragmatics, 38(11), 1901-1927. https://doi.org/10.1016/j.pragma.2005.11.004

Bergman, M., \& Kasper, G. (1993). Perception and Performance in Native and Non-Native Apology. Interlanguage Pragmatics, 4(1), 82-107.

Bergvall, V. B. (1996). Rethinking Language and Gender Research: Theory and Practice. New York: Longman. 
Blum-Kulka, S., \& Olshtain, E. (1984). Requests and Apologies: A Cross-Cultural Study of Speech Act Realisation Patterns (CCSARP). Applied Linguistics, 5(3), 196-213. https://doi.org/10.1093/applin/5.3.196

Brown, P., \& Levinson, S. (1978). Universals in Language Usage: Politeness Phenomena in Questions and Politeness: Strategies in Social Interaction. Cambridge: Cambridge University Press.

Brown, P., \& Levinson, S. (1987). Politeness: Some Universals in Language. Cambridge: Cambridge University Press. https://doi.org/10.1017/CBO9780511813085

Cameron, D. (1997). Performing gender identity: young men's talk and the construction of heterosexual masculinity. In S. M. Johnson (Ed.), Language and Masculinity (pp. 47-64). Oxford: Blackwell.

Celce-Murcia, M., \& Olshtain, E. (2000). Discourse and Context in Language Teaching: A Guide for Language Teachers. Cambridge: Cambridge University Press.

Cohen, A. D., \& Olstain, E. (1981). Developing a Measure of Socio-Cultural Competence: The Case of Apology. Language Learning, 31(3), 113-134. https://doi.org/10.1111/j.1467-1770.1981.tb01375.x

Eelen, G. (2001). A Critique of Politeness Theory. Manchaster: St. Jerome's Press.

Fraser, B., \& Nolan, W. (1981). The Association of Difference with Linguistic Form. International Journal of Sociology of Language, 27, 93-109. https://doi.org/10.1515/ijsl.1981.27.93

Fromkin, V., \& Rodman, R. (1988). An Introduction to Language. New York: Holt, Rinehart \& Winston.

Garcia, C. (1989). Apologizing in English: Politeness Strategies Used by Native and Non-Native Speakers. Multilingua, 8, 3-20. https://doi.org/10.1515/mult.1989.8.1.3

Ghanbari, H., Gowhary, H., \& Azizifar, A. (2015). Investigating Apology Strategy Among Kurdish Bilinguals: A Case Study in Ilam. Procedia - Social and Behavioral Sciences, 199, 204-210. https://doi.org/10.1016/j.sbspro.2015.07.508

Gooder, H., \& Jacobs, J. M. (2000). On the border of the unsayable: the apology in postcolonizing Australia. Interventions, 2, 229-247. https://doi.org/10.1080/136980100427333

Harb, M. (2016). On Gender and Apology Strategies: The Case of Arabic. De Gruyter, 14(1), 224-265. https://doi.org/10.1515/genst-2016-0014

Hatch, E. (1992). Discourse and Language Education. Cambridge: Cambridge University Press.

Holmes, J. (1989). Sex Differences and Apologies: One Aspect of Communicative Competence. Applied Linguistics, 20(2), 194-213. https://doi.org/10.1093/applin/10.2.194

Holmes, J. (1990). Apologies for New Zealand English. Language in Society, 19(2), 155-199. https://doi.org/10.1017/S0047404500014366

Hussein, R. R., \& Hammouri, M. T. (1998). Strategies of Apology in Jordanian Arabic and American English. Grazer Linguistische Studien, 49, 37-51.

Jassim, A. H., \& Nimehchisalem, V. (2016). EFL Arab Students' Apology Strategies in Relation to Formality and Informality of the Context. Ampersand, 3, 117-125. https://doi.org/10.1016/j.amper.2016.06.001

Lakoff, R. T. (1975). Language and Women's Place. New York: Harper \& Row.

Leech, G. N. (1983) The Principle of Pragmatics. London: Longman.

Marquez-Reiter, R. (2000). Linguistic Politeness in Britain and Uruguay: A Contrastive Study of Requests and Apologies. Amsterdam: John Benjamins Publishing Company. https://doi.org/10.1075/pbns.83

Meier, A. (1998). Apologies: What Do We Know? International Journal of Applied Linguistics, 8(2), 215-229. https://doi.org/10.1111/j.1473-4192.1998.tb00130.x

Murphy, J. (2015). Revisiting the Apology as a Speech Act: The Case of Parliamentary Apologies. Journal of Language and Politics, 14(2), 175-204. https://doi.org/10.1075/jlp.14.2.01mur

Norrick, N. (1978). Expressive illocutionary acts. Journal of Pragmatics, 2(3), 277-291. https://doi.org/10.1016/0378-2166(78)90005-X

Olshtain, E. (1989). Apologies to cultures. In S. J. Blum-Kulka (Ed.), Cross-Cultural Pragmatics: Requests and Apologies (pp. 155-173). New Jersey: Ablex, Norwood.

Olshtain, E., \& Cohen, A. (1983). Apology: A speech set act. In N. W. Judd (Ed.), Sociolinguistics and Language Acquisition (pp. 17-33). Rowley: Newbury House. 
Qari, I. (2019). The Gender of the Addressee as a Factor in the Selection of Apology Strategies: The Case of Saudi and British. International Journal of Society, Culture, and Language, 7(1), 83-95.

Reiter, R. M. (2000). Linguistic Politeness in Britain and Uruguay: A Contrastive Study of Request and Apologies. Amsterdam: John Benjamin's Publishing Company. https://doi.org/10.1075/pbns.83

Rizk, S. (1997). Apology in English among Nonnative Arab Speakers of English. Journal of the Faculty of Education, 3, 1-27.

Salgado, E. (2011). The Pragmatic of Requests \& Apologies: Developmental Patterns of Mexican Studies. Amsterdam: John Benjamins Publisheing. https://doi.org/10.1075/pbns.212

Searle, J. (1969). Speech Act: An Essay in the Philosophy of Language. Cambridge: Cambridge University press. https://doi.org/10.1017/CBO9781139173438

Sinan, A. (2004). Pragmatic Analysis of Speech Acts of Arab EFL University Students. National Information Center, Yemen: National Information Center.

Soliman, A. (2003). Apology in American English and Egyptian Arabic. Paper presented at TESOL 3rd Annual Graduate Student Forum.

Sugimoto, N. (1997). A Japan-U.S. comparison of apology styles. Communication Research, 24, 349-370. https://doi.org/10.1177/009365097024004002

Trosborg, A. (1987). Apology Strategies in Natives/Non-Natives. Journal of Pragmatics, 11(2), 144-167. https://doi.org/10.1016/0378-2166(87)90193-7

Vollmer, H. J., \& Olshtain, E. (1989). The language of apologies in German. In S. H. Blum-Kulka (Ed.), Cross-Cultural Pragmatics: Requests and Apologies (pp. 197-218). Rowley: Newbury House.

Wardhaugh, R. (2006). An Introduction to Sociolinguistics. Malden: Blackwell.

Wilson, T. J. (2018). Gender differences in the use of apology strategies in English by Japanese university EFL learners. Bulletin of the Faculty of Liberal Arts 5 (Hiroshima Jogacuin University), 5, 117-125.

\section{Copyrights}

Copyright for this article is retained by the author, with first publication rights granted to the journal.

This is an open-access article distributed under the terms and conditions of the Creative Commons Attribution license (http://creativecommons.org/licenses/by/4.0/). 